\title{
Prediction of body chemical composition of Morada Nova ram lambs using the composition of ribs section between $9^{\text {th }}$ and $11^{\text {th }}$
}

\section{Predição da composição química corporal de cordeiros Morada Nova usando a composição da seção entre a $9^{\text {a }}$ e $11^{\text {a }}$ costelas}

\author{
Marcus Roberto Góes Ferreira Costa ${ }^{1}$; Elzânia Sales Pereira ${ }^{2}$; Andréa Pereira \\ Pinto $^{3 *}$; Aderbal Marcos de Azevêdo Silva ${ }^{4}$; Ariosvaldo Nunes de Medeiros ${ }^{5}$; Ivone \\ Yurika Mizubuti ${ }^{6}$; Edson Luiz de Azambuja Ribeiro'; Ana Cláudia Nascimento \\ Campos $^{3}$; Carla Renata Figueiredo Gadelha ${ }^{3}$; Ronaldo Lopes Oliveira ${ }^{7}$
}

\begin{abstract}
The determination of the chemical composition of the body and carcass is important in nutritional and growth regulation studies. The purpose of this study was to develop equations to predict the chemical composition of the body and carcass using the chemical composition of a section from 9-1 $11^{\text {th }}$ rib in Morada Nova lambs. Forty-eight Morada Nova lambs with an initial weight of $12.05 \pm 1.81 \mathrm{~kg}$, were used. Eight animals were slaughtered at the beginning of the trial as a reference group in order to estimate the initial empty body weight and body composition. The remaining animals were assigned to a randomized block design with eight replications per block and five diets with increasing metabolizable energy contents $(0.96,1.28,1.72,2.18$, and $2.62 \mathrm{Mcal} / \mathrm{kg}$ of dry matter). Animals were slaughtered when the mean of body weight of the group reached $25 \mathrm{~kg}$. Body chemical composition was determined by evaluating the composition of the right half of the carcass, as well as, by using a sample between the $9-11^{\text {th }}$ ribs (the HH section) from the left half of the carcass. According to Pearson's correlation coefficient, the use of the HH section precisely predicted the percentages of protein $(r=0.89)$, ether extract $(r=0.81)$ and minerals $(r=0.83)$. Equations were developed to estimate the percentage of protein, ether extract, ash in the carcass from the following components in the $\mathrm{HH}$ section: $\% \mathrm{CP}$ in the carcass $=-21.05+3.052 * \% \mathrm{CP}$ in the $\mathrm{HH}$ section $\left(\mathrm{r}^{2}=0.83\right) ; \% \mathrm{EE}$ in the carcass $=-6.443+2.879 * \% \mathrm{EE}$ in the HH section $\left(r^{2}=0.76\right) ; \% A s h=4.52-0.362 * \%$ Ash in the HH section $\left(r^{2}=0.15\right)$; \% Water $=$ $7.55+0.878 * \%$ Water in HH section $\left(r^{2}=0.85\right)$. The cut from the $9-11^{\text {th }}$ ribs satisfactorily predicted the protein and ether extract contents in the empty body, with values of $r=0.84$ and 0.78 , respectively. The crude protein and ether extract contents of the empty body can be satisfactorily estimated from chemical composition of the HH section; however, more information must be generated to obtain more reliably applicable equations.
\end{abstract}

Key words: HH section, nutritional requirements, sheep

\footnotetext{
${ }^{1}$ Prof. Dr., Instituto Federal de Educação, Ciência e Tecnologia do Ceará, CE, Brasil. E-mail: mr.goes@gmail.com

${ }^{2}$ Prof $^{a}$ Dr $^{\mathrm{a}}$, Dept ${ }^{\mathrm{o}}$ de Zootecnia, Universidade Federal do Ceará, UFC, Fortaleza, CE, Brasil. Bolsista de Produtividade do CNPq. E-mail: elzania@hotmail.com

${ }^{3}$ Prof $^{\text {s }}$ Dr $^{\text {as }}$, Dept ${ }^{\circ}$ de Zootecnia da UFC, Fortaleza, CE, Brasil. E-mail: deiapp@hotmail.com; anccampos11@gmail.com; crgadelha@yahoo.com.br

${ }^{4}$ Prof. Dr., Unidade Acadêmica de Medicina Veterinária, Universidade Federal de Campina Grande, UFCG, Campina Grande, PB, Brasil. Bolsista de Produtividade do CNPq. E-mail: aderbal@pq.cnpq.br

${ }^{5}$ Prof. Dr., Dept ${ }^{\circ}$ de Zootecnia, Universidade Federal da Paraíba, UFPB, PB, Brasil. E-mail: ariosvaldo.medeiros@gmail.com

${ }^{6}$ Profs. Drs., Dept ${ }^{\circ}$ de Zootecnia, Universidade Estadual de Londrina, UEL, Londrina, PR, Brasil. Bolsista de Produtividade do CNPq. E-mail: mizubuti@uel.br; elar@uel.br

7 Prof. Dr. Dept ${ }^{\circ}$ de Zootecnia, Universidade Federal da Bahia, UFBA, Salvador, BA, Brasil. E-mail: ronaldozootecnista@hotmail.com

* Author for correspondence
} 


\section{Resumo}

A determinação da composição química do corpo e da carcaça é importante em estudos sobre regulação nutricional e do crescimento. O objetivo do presente estudo foi desenvolver equações para predição da composição química do corpo e da carcaça utilizando a composição química da seção entre a 9-11 ${ }^{a}$ costela em cordeiros Morada Nova. Foram utilizados quarenta e oito cordeiros Morada Nova com peso inicial de $12,05 \pm 1,81 \mathrm{~kg}$. Oito animais foram abatidos no início do experimento para servir como grupo referência com o objetivo de estimar o peso do corpo vazio inicial e a composição corporal. Os animais remanescentes foram distribuídos em delineamento em blocos inteiramente casualizados com oito repetições por bloco e cinco dietas contendo níveis crescentes de energia metabolizável $(0,96$; 1,$28 ; 1,72 ; 2,18$ e $2.62 \mathrm{Mcal} / \mathrm{kg}$ de matéria seca). Os animais foram abatidos quando a média de peso corporal do grupo alcançou $25 \mathrm{~kg}$. A composição química corporal foi determinada pela avaliação da composição da meia carcaça direita, bem como, pela utilização de uma amostra entre a 9-11" costela (seção HH) obtida na meia carcaça esquerda. De acordo com o coeficiente de correlação de Pearson, a utilização da seção HH foi sensível para predizer as porcentagens de proteína $(r=0,89)$, extrato etéreo $(\mathrm{r}=0,81)$ e minerais $(\mathrm{r}=0,83)$. Equações foram desenvolvidas para estimar a percentagem de proteína, extrato etéreo, cinzas na carcaça dos seguintes componentes na seção HH: \%PB na carcaça $=-21,05+$ $3,052 * \%$ PB na seção HH $\left(r^{2}=0,83\right) ; \%$ EE na carcaça $=-6,443+2,879 * \%$ EE na seção HH $\left(r^{2}=0,76\right)$; \%Cinzas $=4,52-0,362 * \%$ Cinzas na seção HH $\left(\mathrm{r}^{2}=0,15\right)$; \%Água $=7,55+0,878 * \%$ Água na seção HH $\left(\mathrm{r}^{2}=0,85\right)$. O corte a partir da seção entre as costelas $9-11^{2}$ serviu satisfatoriamente para predizer os conteúdos de proteína e extrato etéreo no corpo vazio, com valores de $\mathrm{r}=0,84$ e 0,78 , respectivamente. Os conteúdos de proteína bruta e extrato etéreo do corpo vazio podem ser satisfatoriamente estimados a partir da composição química da seção $\mathrm{HH}$; contudo, mais informações devem ser geradas para obtenção de equações mais seguramente aplicáveis.

Palavras-chave: Exigência nutricional, ovinos, seção HH

\section{Introduction}

Several countries have already set nutritional norms for their sheep herds, taking into account the peculiarities of their realities (AFRC, 1993; NRC, 2007). In Brazil, many studies have been conducted for estimations of the nutritional requirements of sheep, which will very soon allow performing meta-analysis on many experiments with the goal of publishing a table of nutritional requirements of beef sheep, including hair sheep.

The first step for determining nutritional requirements is to measure the body composition of the animals, which may be obtained by direct or indirect methods. Although the direct determination of body composition by grinding and analyzing all body tissues is the most reliable method, it is expensive, time consuming, and laborious. Numerous methods have been developed to estimate both body and carcass compositions, including linear measurements (KIRTON et al., 1985; TRENKLE, 1986), ultrasound (STANFORD et al., 1985; GUIROY et al., 2001), carcass specific gravity (KRAYBILL; BITTER; HANKINS, 1952; MILLER et al., 1988), dilution techniques (e.g. urea; WELLS; PRESTON, 1998), as well as assessing tritium or deuterium contents (CROOKER; WEBER; ANDREW, 1998). However, some of these methods have inconsistent repeatability, high costs, or are justifiable only under certain experimental conditions (MILLER et al., 1988; STANFORD; JONES; PRICE, 1998).

According to Marcondes, Valadares Filho and Paulino (2009), the method of rib cuts (HANKINS; HOWE, 1946) has been become the validation aim for Brazilian conditions, where studies on cattle, especially Zebu cattle, predominate. Hankins and Howe (1946) found significant correlations of $0.83,0.91$, and 0.53 among the contents of protein, ether extract and ash in the $9-11^{\text {th }}$ rib section $(\mathrm{HH}$ section) and those obtained by chemical analysis of the carcass. In a study on Angus and Holstein cattle, Nour and Thonney (1994) concluded that HH 
section composition can be used with precision for predicting carcass composition, except for minor adjustments with relation to the breed. The indirect method based on the $9-11^{\text {th }}$ cut has been widely used in cattle because it is a cheap and fast method (MARCONDES et al., 2012).

Few attempts have been made to predict the body chemical composition of goats using body parts (FERNANDES et al., 2008). Medeiros (2001) found a high correlation $(r=0.76)$ between the fat chemical composition of the $9-11^{\text {th }}$ rib section and the body fat of Saanen kids. Similarly and Teixeira (2004) reported that the $9-11^{\text {th }}$ rib section and neck had the highest accuracy in predicting the body composition of F1 Saanen $\times$ Boer kids. Teixeira (2004) suggested the use of the neck to estimate the body composition to minimize damage to the carcass due to the removal of the $9-11^{\text {th }}$ rib section. Fernandes et al. (2008) indicated that the chemical composition of organs plus blood and the $9-11^{\text {th }}$ rib section accurately predicted the composition of protein, fat, ash, and water in the body. Nonetheless, more work is needed to evaluate the accuracy and repeatability of this component to predict carcass composition. Therefore, the purpose of this study was to develop equations to predict the chemical composition of the body and carcass using the chemical composition of the $9-11^{\text {th }}$ rib section of Morada Nova lambs.

\section{Material and Methods}

\section{Experimental site}

This trial was conducted at the Department of Animal Science at the Federal University of Ceara, in Fortaleza, state of Ceara (CE), Brazil, from February to June 2010. Humane animal care and handling procedures were followed according to the University's animal care committee.

\section{Animals, housing aad experimental diets}

Forty-eight Morada Nova lambs, non-castrated males, with an average initial body weight (BW) of $12.05 \pm 1.81 \mathrm{~kg}$ at about two months of age, were used. First, the animals were identified, dewormed and placed in individual stalls with feeding troughs to supply the diets and water. After a ten-day adaptation period, eight animals were randomly selected and slaughtered to serve as reference for the empty body weight (EBW) estimates and the initial body composition.

The remaining lambs $(n=40)$ were allocated randomly to five treatments that consisted of increasing levels of metabolizable energy ( 0.96 , $1.28,1.72,2.18$, and $2.62 \mathrm{Mcal} / \mathrm{kg} \mathrm{DM}$ ) obtained from different roughage:concentrate ratios (95:5, 80:20, 60:40, 40:60, and 20:80). The experimental design used was a randomized block with five replications. Tifton 85 hay was used as roughage.

The experimental diets were formulated according to the NRC (2007). Animals were fed twice daily (at 8:00 a.m. and 4:00 p.m.) ad libitum, allowing up to $10 \%$ orts. The diets were fed as a total mixed ration. Daily DM intake (DMI) was determined by difference between the weight of offered and orted diets. Every day, before feeding the animals, the diet orts of each animal were removed and weighted, and data were recorded in spreadsheets for daily control. Samples of feed and orts were weighed daily, sampled and frozen for subsequent chemical analysis.

\section{Diet digestibility determination and prediction of diet metabolizable energy}

Digestibility trials were conducted eight times throughout the experiment to determine the metabolizable energy (ME) of the diet. Indigestible neutral detergent fiber (iNDF) was used as a marker to estimate fecal dry matter excretion, as described by Casali et al. (2008). Faeces were collected for three consecutive days, every 15 days during the 
experimental period, at 8:00 a.m. on the first day, at noon on the second day, and at 4:00 p.m. on the third day.

The amount of iNDF in the faecal samples, orts, concentrates, and Tifton 85 hay were obtained through in situ incubations over a period of 240 hours in the rumen of a cow. After this period, the samples were washed in water until it became totally clear. Subsequently, they were boiled for 1 hour in a neutral detergent solution (VAN SOEST; ROBERTSON; LEWIS, 1991), washed with boiling water, then acetone, and finally dried in a forcedair oven at $55^{\circ} \mathrm{C}$ for 24 hours. The remains were weighed and considered to be the iNDF (CASALI et al., 2008).

The dietary digestible energy (DE) was estimated to be $4.409 \mathrm{Mcal} / \mathrm{kg}$ of the total digestible nutrients (TDN), and DE was converted to metabolizable energy (ME) using an efficiency of $82 \%$ (NRC, 2000).

\section{Chemical analysis}

Forage, concentrate and refuse samples were dried in a forced air oven at $55^{\circ} \mathrm{C}$ for 72 hours, then ground in a knife mill with a $1 \mathrm{~mm}$ screen (Wiley mill, Arthur H. Thomas, Philadelphia, PA, USA). The samples were analyzed for contents of dry matter (DM; AOAC, 1990; method number
930.15), mineral matter (MM; AOAC, 1990; method number 924.05), crude protein (CP; AOAC, 1990; method number 984.13), ether extract (EE; AOAC, 1990; method number 920.39), and acid detergent fiber (ADF; AOAC, 1990; method number 973.18). To analyze neutral detergent fiber (NDF), the samples were treated with thermostable alpha-amylase without using sodium sulfite, and corrected for residual ash (MERTENS, 2002) and residual nitrogenous compounds (LICITRA; HERNANDEZ; VAN SOEST, 1996). The total carbohydrate content (TC) was calculated according to Sniffen et al. (1992) (Eq.[1]):

$$
\mathrm{TC}(\%)=100-(\% \mathrm{CP}+\% \mathrm{EE}+\% \text { ash })
$$

The non-fibrous carbohydrates (NFC) were calculated using the equation adapted from Weiss (1999) (Eq. [2]):

NFC $(\%)=100-(\%$ NDFap $+\% \mathrm{CP}+\% \mathrm{EE}+\%$ ash $)(2)$

For the concentrates, due to the presence of urea in their formation, the NFC was calculated using the adapted equation from Hall (2000) (Eq.[3]):

$\mathrm{NFC}=100-((\% \mathrm{CP}-\% \mathrm{CP}$ derived from urea $+\%$

of the urea) $+\%$ NDFap $+\%$ EE $+\%$ ash)

Diets were composed of Tifton 85 hay (as roughage) and concentrates based on corn grain, soybean meal, urea, limestone, dicalcium phosphate, sodium chloride, and a mineral premix (Tables 1 and 2).

Table 1. Chemical composition of the ingredients in $\mathrm{g} / \mathrm{kg} \mathrm{DM}$.

\begin{tabular}{lcccccccc}
\hline \multirow{2}{*}{ Nutrient $(\mathrm{g} / \mathrm{kg})$} & \multirow{2}{*}{$\begin{array}{c}\text { Tifton } \\
\text { hay }\end{array}$} & \multirow{2}{*}{$\begin{array}{c}\text { Corn } \\
\text { meal }\end{array}$} & $\begin{array}{c}\text { Soybean } \\
\text { meal }\end{array}$ & \multicolumn{7}{c}{ Concentrate } \\
\cline { 6 - 9 } Dry matter & 953.6 & 891.0 & 951.8 & 967.0 & 962.4 & 954.3 & 958.3 & 947.3 \\
Organic matter & 873.8 & 879.3 & 885.7 & 930.4 & 889.2 & 911.9 & 919.5 & 903.2 \\
Crude protein & 78.9 & 91.4 & 546.3 & 298.6 & 525.5 & 279.3 & 221.3 & 188.9 \\
Ether extract & 14.6 & 53.9 & 29.1 & 25.4 & 29.7 & 36.7 & 34.2 & 30.8 \\
Ash & 79.8 & 11.7 & 66.1 & 36.6 & 73.2 & 42.4 & 38.8 & 44.1 \\
NDF $^{\mathrm{A}}$ & 754.0 & 176.6 & 154.3 & 128.7 & 132.0 & 142.9 & 140.6 & 145.8 \\
NDIN $^{\mathrm{B}}$ & 0.44 & 0.38 & 0.56 & 0.14 & 0.23 & 0.14 & 0.15 & 0.14 \\
ADF $^{\mathrm{C}}$ & 447.2 & 82.8 & 145.4 & 96.7 & 75.2 & 44.0 & 48.6 & 47.2 \\
ADIN & 2.66 & 5.44 & 0.38 & 0.04 & 0.32 & 0.04 & 0.04 & 0.04 \\
& & & & & & & & continua
\end{tabular}


continuação

\begin{tabular}{lcccccccc} 
Lignin & 51.2 & 8.1 & 37.3 & 9.5 & 13.8 & 16.4 & 18.9 & 19.4 \\
Cellulose & 304.4 & 24.1 & 55.3 & 35.7 & 72.0 & 33.7 & 33.5 & 35.3 \\
Hemicellulose & 306.8 & 93.8 & 8.9 & 32.0 & 56.8 & 98.9 & 92.0 & 98.6 \\
TC $^{\mathrm{E}}$ & 826.7 & 842.9 & 358.4 & 675.1 & 393.6 & 662.0 & 680.6 & 693.7 \\
$\mathrm{FC}^{\mathrm{F}}$ & 701.3 & 138.8 & 104.2 & 96.0 & 99.5 & 110.7 & 95.3 & 104.0 \\
$\mathrm{NFC}^{\mathrm{G}}$ & 125.3 & 704.1 & 254.2 & 579.1 & 294.1 & 551.3 & 585.3 & 589.7 \\
\hline
\end{tabular}

${ }^{\mathrm{A}} \mathrm{NDF}=$ neutral detergent fiber.

${ }^{B} \mathrm{NDIN}=$ neutral detergent insoluble nitrogen.

${ }^{\mathrm{C}} \mathrm{ADF}=$ acid detergent fiber.

${ }^{\mathrm{D}} \mathrm{ADIN}=$ acid detergent insoluble nitrogen.

ETC $=$ total carbohydrates.

${ }^{\mathrm{F}} \mathrm{FC}=$ fibrous carbohydrates.

${ }^{\mathrm{G}} \mathrm{NFC}=$ non-fibrous carbohydrates.

Source: Elaboration of the authors.

Table 2. Composition of the experimental diets.

\begin{tabular}{|c|c|c|c|c|c|}
\hline \multirow{2}{*}{ Ingredient } & \multicolumn{5}{|c|}{ Level of metabolizable energy (Mcal/kg DM) } \\
\hline & 0.96 & 1.28 & 1.72 & 2.18 & 2.62 \\
\hline Tifton hay & 95 & 80 & 60 & 40 & 20 \\
\hline Concentrate & 5 & 20 & 40 & 60 & 80 \\
\hline Corn meal ${ }^{\mathrm{A}}$ & 626.3 & 158.7 & 694.5 & 724.6 & 756.1 \\
\hline Soybean meal ${ }^{\mathrm{A}}$ & 326.2 & 806.5 & 285.3 & 248.8 & 225.9 \\
\hline Urea $^{\mathrm{A}}$ & 37.7 & 30.0 & 12.5 & 11.2 & 5.1 \\
\hline Limestone $^{\mathrm{A}}$ & - & - & - & 5.4 & 6.6 \\
\hline Dicalcium phosphate ${ }^{\mathrm{A}}$ & - & - & - & - & 0.7 \\
\hline Sodium chloride ${ }^{\mathrm{A}}$ & 8.6 & 4.0 & 7.0 & 9.3 & 5.0 \\
\hline Mineral premix ${ }^{\mathrm{A}, \mathrm{B}}$ & 1.2 & 0.8 & 0.7 & 0.7 & 0.6 \\
\hline \multicolumn{6}{|l|}{ Chemical components } \\
\hline Dry matter $(\mathrm{g} / \mathrm{kg})$ & 954.3 & 955.4 & 953.9 & 956.4 & 951.2 \\
\hline $\operatorname{Ash}(g / k g ~ D M)$ & 38.0 & 78.5 & 64.8 & 55.2 & 51.2 \\
\hline Crude protein (g/kg DM) & 89.9 & 168.2 & 159.1 & 164.4 & 166.9 \\
\hline Ether extract (g/kg DM) & 24.9 & 26.7 & 27.9 & 22.4 & 27.6 \\
\hline Neutral detergent fiber (g/kg DM) & 722.5 & 629.6 & 509.6 & 386.0 & 267.4 \\
\hline Acid detergent fiber (g/kg DM) & 429.6 & 372.8 & 285.9 & 208.0 & 127.2 \\
\hline $\operatorname{Lignin}(g / k g ~ D M)$ & 49.1 & 43.7 & 37.3 & 31.8 & 25.8 \\
\hline Cellulose (g/kg DM) & 293.2 & 259.8 & 197.6 & 142.8 & 89.6 \\
\hline Hemicellulose (g/kg DM) & 293.0 & 256.8 & 223.7 & 178.0 & 140.2 \\
\hline Fibrous carbohydrates (g/kg DM) & 671.1 & 581.0 & 465.1 & 337.7 & 223.5 \\
\hline Total carbohydrates (g/kg DM) & 817.3 & 735.7 & 764.6 & 754.0 & 746.3 \\
\hline Non fiber carbohydrate (g/kg DM) & 146.2 & 154.7 & 299.5 & 416.3 & 522.8 \\
\hline $\mathrm{TDN}^{\mathrm{C}}(\mathrm{g} / \mathrm{kg} \mathrm{DM})$ & 280.1 & 344.6 & 453.9 & 593.9 & 723.6 \\
\hline $\mathrm{TDN}: \mathrm{CP}^{\mathrm{D}}$ & 3.12 & 2.04 & 2.85 & 3.61 & 4.33 \\
\hline
\end{tabular}

${ }^{\mathrm{A}}$ Centesimal concentration in relation to the concentrated portion of the diets.

${ }^{\mathrm{B} C}$ Composition: Ca 7.5\%; P 3\%; Fe 16.500 ppm; Mn 9.750 ppm; Zn 35.000 ppm; I 1000 ppm; Se 225 ppm; Co 1000 ppm.

${ }^{\mathrm{C}}$ Total digestible nutrients.

DTotal digestible nutrients:Crude protein.

Source: Elaboration of the authors. 


\section{Performance and slaughter procedures}

Animals were weighed weekly to follow the average weight gain (AWG), and when the BW mean of the treatment reached $25 \mathrm{~kg}$, the animals were slaughtered. On this occasion, one animal from the group with the lowest energy concentration in the diet was also slaughtered (animals placed in the treatment with $0.96 \mathrm{Mcal} / \mathrm{kg} \mathrm{DM}$ of ME). This procedure was carried out for each group until all the animals were slaughtered. Before slaughter, shrunk body weight (SBW) was measured as the BW after 18 hours of feed and water fast. At slaughter, lambs were stunned by using a cash knocker and killed by exsanguination by using conventional humane procedures.

Blood was weighed and sampled. The gastrointestinal tract was weighed full, then emptied, washed out, and weighed again after draining together with the weight of the organs and other body parts (carcass, head, skin, blood, hooves, and tail). The body was separated into individual components, which were weighed separately. This included the internal organs (liver, heart, trachea + lungs + tongue + esophagus, bladder, kidneys, reproductive tract, and spleen), the cleaned digestive tract (rumen, reticulum, omasum, abomasum, and small and large intestines) and fats (omental, perirenal, mesenteric, and heart fat). The empty body weight (EBW) was computed as SBW at slaughter minus the digestive tract contents.

After slaughter, all carcasses were weighed hot (approximately $1 \mathrm{~h}$ after slaughter) and then after cooling at $-4^{\circ} \mathrm{C}$ for approximately $24 \mathrm{~h}$. After 24 $\mathrm{h}$ of chilling, the chilled carcasses were weighed again and then cutted longitudinally in half with a band saw. The $9-11^{\text {th }}$ rib section (the $9^{\text {th }}, 10^{\text {th }}$, and $11^{\text {th }}$ ribs, according Hankins and Howe (1946)) was removed from the left carcass.

The organs, blood, paws, and head were ground together with the right half carcass and the $9-11^{\text {th }}$ rib section in an industrial meat grinder. The feet were cut into cubes and were pre-degreased by immersion in petroleum ether. The samples of each animal were thawed, dried in an oven with air circulation at $55^{\circ} \mathrm{C}$, then ground in a blender. The mass of ground organs + blood + feet + head and right half carcass and leather were homogenized, sampled and placed in a forced ventilation oven at $55^{\circ} \mathrm{C}$ for 72 hours. The pre-dried samples were processed with a multiprocessor.

After this procedure, the samples were defatted by extraction in ether in a Soxhlet apparatus (AOAC, 1990; method number 920.39). After extraction with ether, the samples were ground in a ball mill and stored in closed containers. The dry matter contents (defatted) were treated in an oven at $105^{\circ} \mathrm{C}$ to a constant weight, then the ash and crude protein levels were determined as described for the ingredients of the experimental diets on fat-free samples.

\section{Statistical analyses}

The experimental design was a randomized block (initial body weight), with five treatments, according to the mathematical model Yij $=\mu+\alpha i+$ $\beta j+$ eij, where Yij $=$ the value observed in the plot that received the treatment $\mathrm{i}$ in the block $\mathrm{j} ; \mu=$ the general average of the population; $\alpha i=$ the effect of the treatment $i=1,2,3,4,5 ; \beta i=$ the effect of the block $\mathrm{j}=1,2$; eij $=$ random error.

The prediction of body chemical composition by means of the methodology described by Hankins and Howe (1946) was evaluated for its precision by using Pearson's correlation coefficient (r) and, because of its accuracy, by adjusting the linear regression equation between the predicted (independent variable) and observed (dependent variable) values. Equation parameters were tested jointly in the following hypothesis by the $\mathrm{F}$ test: $\mathrm{F}$ : $\mathrm{H}_{0}: \beta_{0}=0$ and $\beta_{1}=1, \mathrm{H}_{\mathrm{a}}=\operatorname{not} \mathrm{H}_{0}$.

Data estimated by section between the $9^{\text {th }}$ and $11^{\text {th }}$ ribs and observed in the carcass and in the empty body were compared by means of regression 
analysis, so $\mathrm{H}_{0}: \beta_{0}=0$ and $\beta_{1}=1$ and $\mathrm{H}_{\mathrm{a}}$ : not $\mathrm{H}_{0}$. A significant difference was found between the observed and estimated values with a $\mathrm{P}$ value lower than 0.05 .

The statistical analyses were performed using PROC GLM of SAS version 9.0 (SAS, 2003). An orthogonal partition of the sum of the square of treatments into linear, quadratic and cubic degree effects was obtained by analysis of variance. The regression equation was adjusted when significance was observed, using PROC REG SAS (9.0).

\section{Results and Discussion}

Statistical analyses of the regressions found in this study (Table 3 ) showed that the null hypothesis for the four chemical components was not rejected, i.e., the $\mathrm{HH}$ section provides a satisfactory estimate of the ether extract and crude protein contents in the carcass of Morada Nova sheep (Table 4).

Table 3. Estimates of parameters, descriptive values of probability for null hypothesis, coefficient of determination $\left(\mathrm{r}^{2}\right)$ and Pearson's correlation coefficient (r) for estimated and observed values of the percentages of ether extract, crude protein, ash and water.

\begin{tabular}{lcccccc}
\hline \multirow{2}{*}{ Item } & \multicolumn{7}{c}{ Regression } \\
\cline { 2 - 7 } & \multicolumn{2}{c}{ Intercept } & Inclination coefficient & & \\
\cline { 2 - 7 } & Estimate & P Value & Estimate & P value & $\mathrm{r}^{2}$ & $\mathrm{r}$ \\
\hline Ether extract & 0.830 & 0.003 & 0.867 & $* * *$ & 0.66 & 0.81 \\
Crude protein & 1.794 & 0.021 & 1.041 & $* * *$ & 0.79 & 0.88 \\
Ash & 11.251 & 0.817 & 0.555 & 0.865 & 0.68 & 0.83 \\
Water & 7.552 & 0.065 & 0.878 & $* * *$ & 0.87 & 0.93 \\
\hline
\end{tabular}

Source: Elaboration of the authors.

Ether extract content obtained by means of the $\mathrm{HH}$ section was underestimated in $18.27 \%$ and the ash content was overestimated in $54.71 \%$ (Figure 1). For crude protein values, the content of this component in the section $\mathrm{HH}$ appeared lower than value of $0.83 \%$ obtained directly from the carcass (Table 4).

By evaluating the estimate of carcass chemical composition by means of the $\mathrm{HH}$ section, a satisfactory correlation was observed between the estimated and the observed values for protein, ether extract, and ash. The best Pearson's correlation coefficient ( $\mathrm{r}$ ) was found for water content $(\mathrm{r}=$ $0.93)$, followed by protein $(\mathrm{r}=0.88)$, ash $(\mathrm{r}=$ $0.83)$, and ether extract content $(\mathrm{r}=0.81)$ (Table 3$)$. Hankins and Howe (1946) observed a significant correlation of 0.83 for protein in the prediction for chemical composition in cattle carcasses, a value close to the one obtained in the present experiment. Powel and Huffman (1968), when evaluating different methods of carcass chemical composition prediction, reported that the method developed by Hankins and Howe (1946) was the most accurate method for the estimation of ether extract $\left(r^{2}=0.94\right)$ and protein content $\left(r^{2}=0.96\right)$ in the carcass. 
Table 4. Means and amplitudes of variation for percentages of ether extract, crude protein, ash and water in the carcass of animals and in the $\mathrm{HH}$ section.

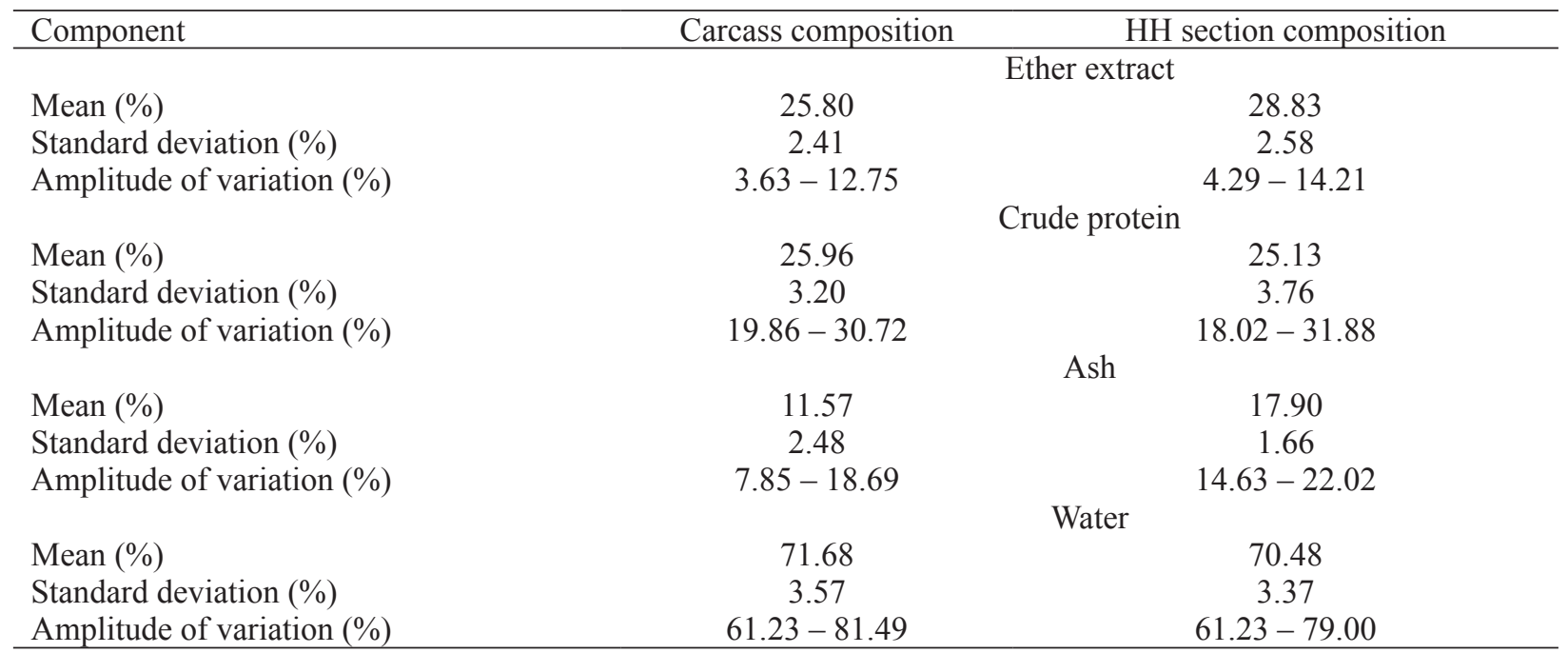

Source: Elaboration of the authors.

Figure 1 Relationship between the contents of the ether extract (EE), crude protein (CP), ash and water observed in the carcass and in the $\mathrm{HH}$ section.
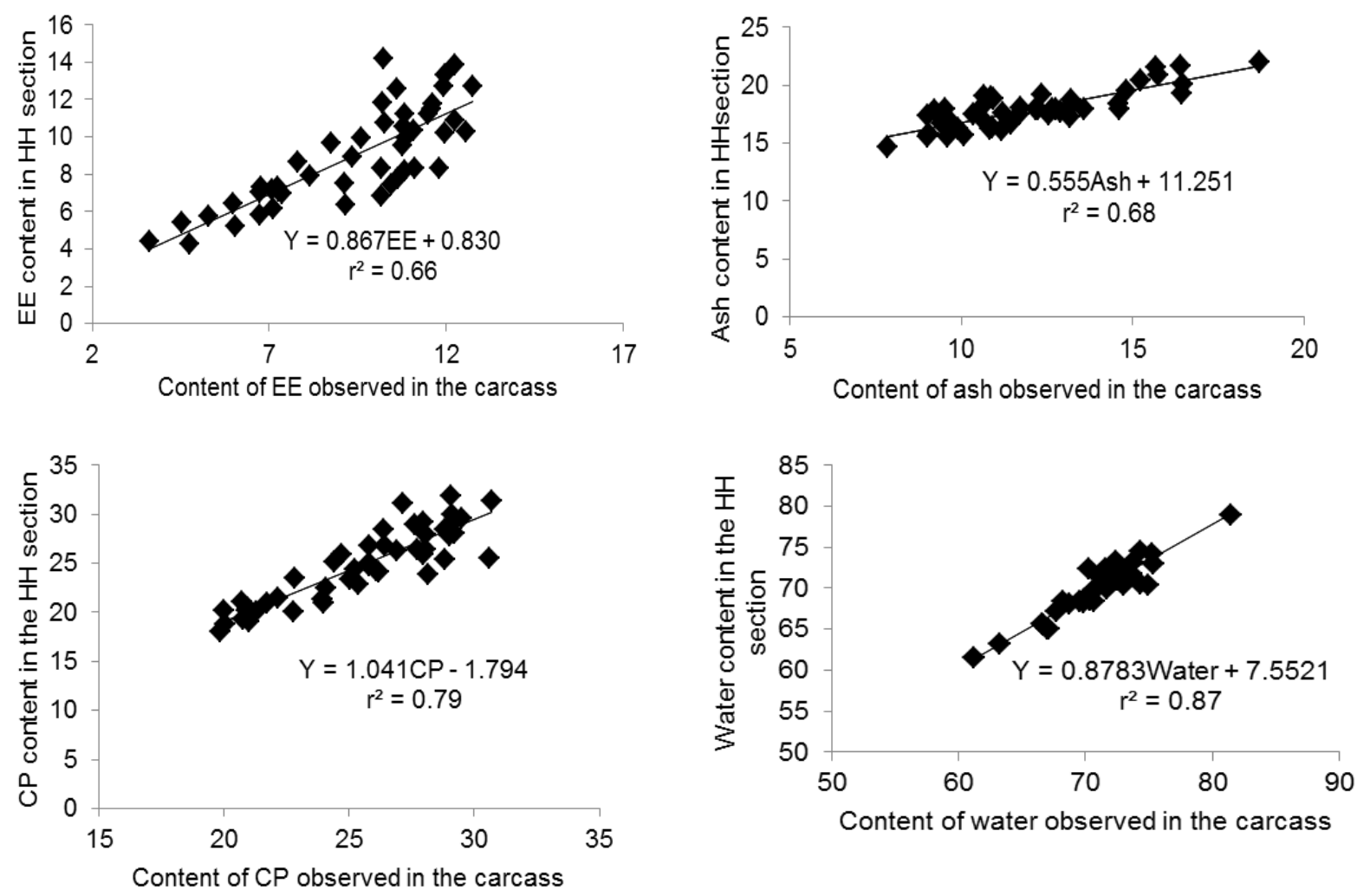

Source: Elaboration of the authors. 
According to Marcondes, Valadares Filho and Paulino (2009), for an indirect estimation of the chemical composition of an animal, equation to estimate these values from chemical composition of the $\mathrm{HH}$ section are needed. Some studies have already been carried out in Brazil to estimate in cattle, and some equations have been developed (SILVA et al., 2002; HENRIQUE et al., 2003; PAULINO et al., 2005). Valadares Filho, Paulino and Magalhães (2006) compiled Brazilian data and elaborated equations for predicting water, ether extract, protein, and minerals contents in the empty body weight of Zebu cattle, but additional studies for validation of these equations are needed.

The parameters of the regression equation percentages observed in the empty body for ether extract, crude protein, ash and water, according to the percentages of these components in the cutting of the $9-11^{\text {th }}$ ribs, are in Table 5 .

Table 5. Relationships among chemical components observed in the empty body and estimated by means of the HH section in Morada Nova lambs.

\begin{tabular}{lcccc}
\hline Component & Estimating equation & Mean standard error & $\mathrm{r}^{2}$ & $\mathrm{r}$ \\
\hline Ether extract (EE) & $\mathrm{Y}=0.238+0.952 \mathrm{X}$ & 1.39 & 0.89 & 0.94 \\
Crude protein (CP) & $\mathrm{Y}=-1.226+1.035 \mathrm{X}$ & 1.42 & 0.90 & 0.95 \\
Ash & $\mathrm{Y}=12.254+0.4696 \mathrm{X}$ & 1.67 & 0.13 & 0.37 \\
Water & $\mathrm{Y}=11.696+0.828 \mathrm{X}$ & 1.27 & 0.85 & 0.92 \\
\hline
\end{tabular}

$\mathrm{Y}=$ estimate chemical component; $\mathrm{X}=$ component in $\mathrm{HH}$ section

Source: Elaboration of the authors.

Thus, the composition of the empty body of Morada Nova sheep was estimated (Table 6) based on protein, fat, ash, and water contents in the $\mathrm{HH}$ section. The observed values for ether extract, protein and water contents of the empty body were highly correlated (Figure 2) with estimated values using the chemical composition of the HH section for protein, fat, and water, with values of Pearson's correlation coefficient (r) equal to $0.94,0.95$ and 0.92, respectively. Peron et al. (1993), working with cattle, found significant correlations of 0.93 and 0.99 for protein and fat, respectively. Henrique et al. (2003) and Alleoni et al. (1997) also concluded that the percentage of ether extract in the empty body estimated by the $\mathrm{HH}$ section was highly correlated with the chemical composition of the empty body.

The results reported by Hankins and Howe (1946) and Kelly et al. (1968), when working with cattle in a study comparing the content of minerals in 9-11 $1^{\text {th }}$ rib cuts with the contents found in the carcass, found lower coefficients of correlation, which led the authors to conclude that the use of this cut for predicting the content of minerals in the carcass would be questionable. Linear regression between the empty body composition and the composition of the $\mathrm{HH}$ section was done to obtain prediction equations of the chemical composition of the empty body (EB) (Table 3).

Values of the contents of ether extract, protein, and water of the empty body estimated using the chemical composition of the $\mathrm{HH}$ section were close to the values observed when the chemical composition of the carcass was used for determining the body content of the empty body (Table 6). For ash content in the empty body, the value obtained was overestimated by $39.90 \%$ when the chemical composition of the HH section was used (Figure 2). 
Table 6. Means and amplitude of variation for percentages of ether extract, crude protein, ash and water observed in the empty body and estimated by means of the HH section.

\begin{tabular}{|c|c|c|}
\hline Component & Observed composition & Estimated composition \\
\hline & \multicolumn{2}{|c|}{ Ether extract } \\
\hline Mean $(\%)$ & 9.64 & 9.20 \\
\hline Standard error $(\%)$ & 2.55 & 2.57 \\
\hline \multirow[t]{2}{*}{ Amplitude of variation (\%) } & $3.01-12.57$ & $2.42-12.47$ \\
\hline & \multicolumn{2}{|c|}{ Crude protein } \\
\hline Mean $(\%)$ & 22.53 & 22.20 \\
\hline Standard error $(\%)$ & 2.69 & 2.93 \\
\hline \multirow[t]{2}{*}{ Amplitude of variation (\%) } & $18.13-27.99$ & $17.04-28.61$ \\
\hline & \multicolumn{2}{|c|}{ Ash } \\
\hline Mean $(\%)$ & 10.63 & 17.69 \\
\hline Standard error $(\%)$ & 1.77 & 2.26 \\
\hline \multirow[t]{2}{*}{ Amplitude of variation (\%) } & $8.68-14.84$ & $10.01-20.89$ \\
\hline & \multicolumn{2}{|c|}{ Water } \\
\hline Mean $(\%)$ & 65.95 & 68.03 \\
\hline Standard error $(\%)$ & 3.62 & 3.25 \\
\hline Amplitude of variation (\%) & $60.09-75.76$ & $63.46-74.71$ \\
\hline
\end{tabular}

Source: Elaboration of the authors.

Figure 2. Relationship between the observed contents of ether extract (EE), crude protein (CP), ash and water in the empty body (EB) and estimated by means of the HH section.
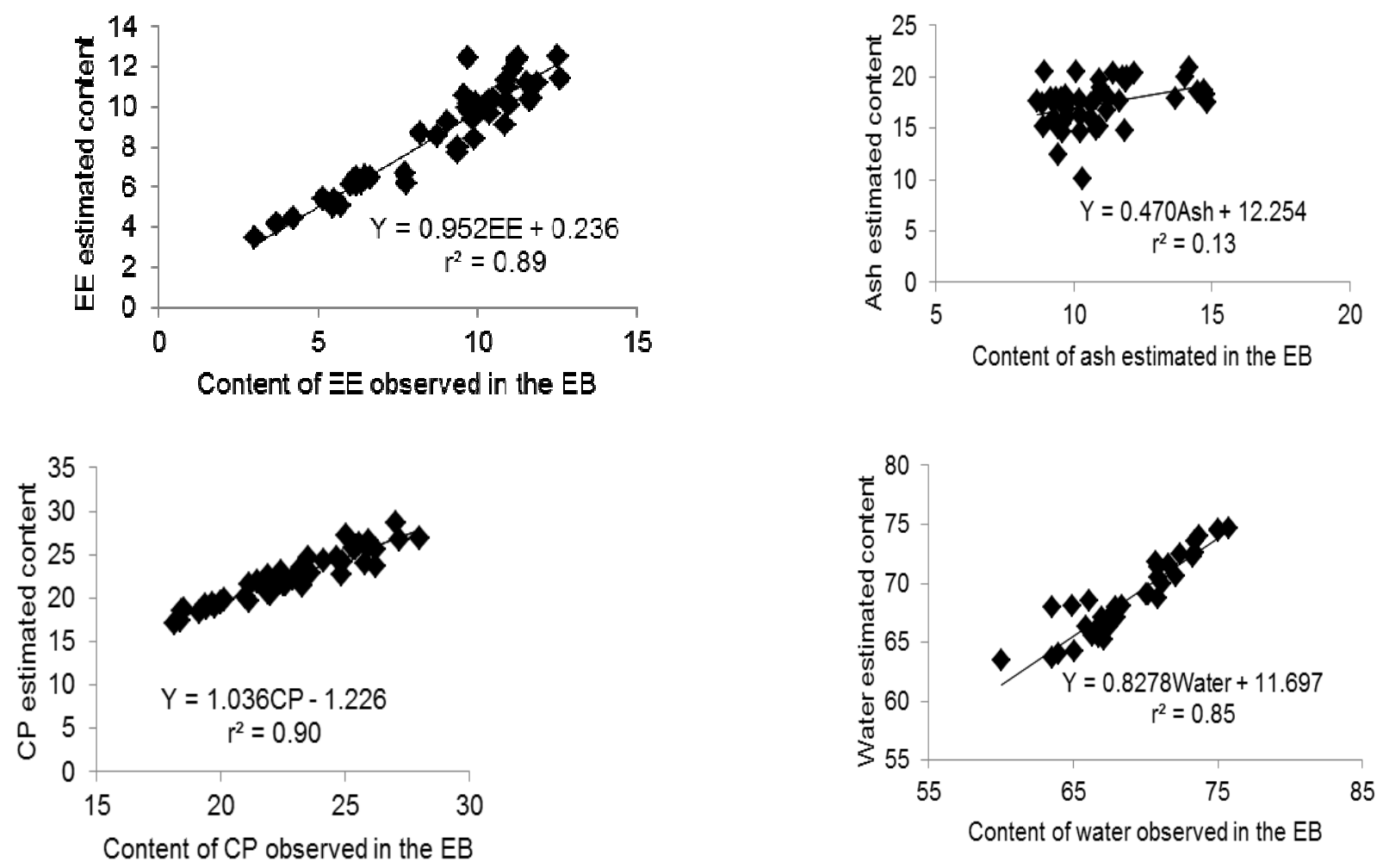

Source: Elaboration of the authors. 
According to Paulino et al. (2005), although the coefficient of determination obtained by regression between the values of ash content in the EB estimated using the chemical composition of $\mathrm{HH}$ section and the one obtained using the carcass composition were lower than those concerning the protein and ether extract contents, this does not invalidate the method of estimation, as was previously discussed for the estimation of the physical composition of the carcass.

The generated equations did not reflect a high degree of precision for the mineral content, as well as, the one obtained for the other constituents. Several authors have pointed out lower precision of the estimate of mineral contents in the empty body or in the carcass from the composition of ribs cuts (HANKINS; HOWE, 1946; LANNA et al., 1995; HENRIQUE et al., 2003).

The 9-1 ${ }^{\text {th }}$ rib section has been widely used to predict body (LANNA et al., 1995; ALLEONI et al., 1997) and carcass (HANKINS; HOWE, 1946, MILLER et al., 1988; LANNA et al., 1995) composition in cattle. Medeiros (2001) and Teixeira (2004) reported a high-precision body composition estimate using the chemical composition of the $9-11^{\text {th }}$ ribs in goats. However, the inclination and intercepts of the regressions differed according to the population. The results showed that the section $\mathrm{HH}$ was moderately accurate and precise in predicting body fat, but it was unsatisfactory in the prediction of protein, water and ash body content (FERNANDES et al., 2008).

The equations adjusted for ether extract and protein contents in the empty body presented high coefficients of determination and reduced estimation standard errors as a function of the ether extract and protein contents in the HH section, which allows us highly precisely infer that it is possible to estimate body composition from the $9-11^{\text {th }}$ ribs of Morada Nova lambs, corroborating the results described by Paulino et al. (2005) for Nellore x Bos taurus crossbred cattle.
From ether extract, protein, ash and water carcass and chemical composition of the section between the $9^{\text {th }}$ and $11^{\text {th }}$ ribs were obtained equations for predicting chemical composition of the empty body for Morada Nova lambs:

$\% \mathrm{EE}=-6.443+2.879 * \% \mathrm{EE}$ in $\mathrm{HH}$ section $\left(\mathrm{r}^{2}=\right.$ $0.76)$;

$\% \mathrm{CP}=-21.05+3.052 * \% \mathrm{CP}$ in $\mathrm{HH}$ section $\left(\mathrm{r}^{2}=\right.$ $0.83)$;

$\%$ Ash $=4.52-0.362 * \%$ Ash in $\mathrm{HH}$ section $\left(\mathrm{r}^{2}=\right.$ $0.15)$;

$\%$ Water $=7.55+0.878 * \%$ Water in $\mathrm{HH}$ section $\left(\mathrm{r}^{2}=\right.$ $0.85)$

\section{Conclusion}

The results presented in this study indicate that the chemical composition of the organs plus blood and the $9-11^{\text {th }}$ rib section accurately predict the composition of protein, fat, ash, and water in the body in Morada Nova lambs.

Further experiments should be conducted with more animals to assess the validity of the results obtained in this experiment.

\section{References}

AGRICULTURAL AND FOOD RESEARCH COUNCIL - AFRC. Energy and protein requirements of ruminants. Wallingford: Commonwealth Agricultural Bureaux International, 1993. $159 \mathrm{p}$.

ALLEONI, G. F.; LEME, P. R.; BOIN, C.; NARDON, R. F.; DEMARCHI, J. J. A. A.; VIEIRA, P. F.; TEDESCHI, L. O. Avaliação da composição química e física dos cortes da costela para estimar a composição química corporal de novilhos Nelore. Revista Brasileira de Zootecnia, Viçosa, v. 26, n. 2, p. 382-390, 1997.

ASSOCIATION OF OFFICIAL ANALYTICAL CHEMISTS - AOAC. Official methods of analysis. $15^{\text {th }}$ ed. Virginia: Arlington, 1990. 1298 p.

CASALI, A. O.; DETMANN, E.; VALADARES FILHO, S. C.; PEREIRA, J. C.; HENRIQUES, L. T.; FREITAS, S. G.; PAULINO, M. F. Influência do tempo de incubação e do tamanho de partículas sobre os teores de compostos 
indigestíveis em alimentos e fezes bovinas obtidos por procedimentos in situ. Revista Brasileira de Zootecnia, Viçosa, v. 37, n. 2, p. 335-342, 2008.

CROOKER, B. A.; WEBER, W. J.; ANDREW, S. M. Development and use of deuterium oxide dilution equations to predict body composition of Holstein cows. In ENERGY METABOLISM OF FARM ANIMALS, 14., 1998, Wallingford. Proceddings... CAB International: Wallingford, UK, 1998. p. 177-180.

FERNANDES, M. H. M. R.; RESENDE, K. T.; TEDESCHI, L. O.; FERNANDES JUNIOR, J. S.; TEIXEIRA, I.; CARSTENS, G. E.; BERCHIELLI, T. T. Predicting the chemical composition of the body and the carcass of $3 / 4$ Boer $\times 1 / 4$ Saanen kids using body components. Small Ruminants Research, Newton, v. 75, n. 1, p. 90-98, 2008.

GUIROY, P. J.; FOX, D. G.; TEDESCHI, L. O.; BAKER, M. J.; CRAVEY, M. D. Predicting individual feed requirements of cattle fed in groups. Journal of Animal Science, Champaign, v. 79, n. 8, p. 1983-1995, 2001.

HALL, M. B. Calculation of non-structural carbohydrate content of feeds that contain non-protein nitrogen. Gainesville: University of Florida, 2000. (Bulletin, n. 339: A25).

HANKINS, O. G.; HOWE, P. E. Estimation of the composition of beef carcasses and cuts. Washington: United States Department of Agriculture, 1946. 20 p. (Technical Bulletin, 926).

HENRIQUE, W.; SAMPAIO, A. A. M.; LEME, P. R.; ALLEONI, D. F.; LANNA, D. P. D. Estimativa da composição química corporal de tourinhos Santa Gertrudis a partir da composição química e física das $9^{\mathrm{a}}-10^{\mathrm{a}}-11^{\mathrm{a}}$ costelas. Revista Brasileira de Zootecnia, Viçosa, v. 32, n. 3, p. 709-718, 2003.

KELLY, R. F.; FONTENOT, J. P.; GRAHAM, P. O.; WILKISON, W. S.; KINCAID, C. M. Estimates of carcass composition of beef cattle fed at different planes od nutrition. Journal of Animal Science, Champaign, v. 27, n. 3, p. 620-627, 1968.

KIRTON, A. H.; DUGANZICH, D. M.; FEIST, C. L.; BENNETT, G. L.; WOODS, E. G. Prediction of lamb carcass composition from GR and carcass weight. In: NEW ZEALAND SOCIETY OF ANIMAL PRODUCTION, 45., 1985, New Zealand. Proceedings... New Zealand: New Zealand Soc. Anim. Prod., 1985. p. 63-65.

KRAYBILL, H. F.; BITTER, H. L.; HANKINS, O. G. Body composition of cattle. II. Determination of fat and water content from measurement of body specific gravity. Journal of Applied Physiology, Bethesda, v. 4, n. 7, p. 575-583, 1952.
LANNA, D. P. D.; BOIN, C.; ALLEONI, G. F.; LEME, P. R. Estimativa da composição química corporal de tourinhos nelore através da gravidade específica. Revista Brasileira de Zootecnia, Viçosa, v. 24, n. 3, p. 351-362, 1995.

LICITRA, G.; HERNANDEZ, T. M.; VAN SOEST, P. J. Standardization of procedures for nitrogen fractionation of ruminant feeds. Animal Feed Science and Technology, Amsterdam, v. 57, n. 4, p. 347-358, 1996.

MARCONDES, M. I.; TEDESCHI, L. O.; VALADARES FILHO, S. C.; CHIZZOTTI, M. L. Prediction of physical and chemical body compositions of purebred and crossbred Nellore cattle using the composition of a rib section. Journal of Animal Science, Champaign, v. 90, n. 4, p. 1280-1290, 2012.

MARCONDES, M. I.; VALADARES FILHO, S. C.; PAULINO, P. V. R. Predição da composição corporal e da carcaça a partir da seção entre a $9^{\mathrm{a}}$ e $11^{\mathrm{a}}$ costelas em bovinos Nelore. Revista Brasileira de Zootecnia, Viçosa, v. 38, n. 8, p. 1597-1604, 2009.

MEDEIROS, A. N. Body composition and net energy and protein requirements for maintenance and weight gain for goats Saanen in the initial growth. 2001. PhD Thesis (Doctor in Animal Science) - State University of São Paulo, São Paulo.

MERTENS, D. R. Gravimetric determination of amylasetreated neutral detergent fiber in feeds with refluxing in beakers or crucibles: collaborative study. Journal of AOAC International, Gaithersburg, v. 85, n. 6, p. 1217 1240, 2002.

MILLER, M. F.; CROSS, H. R.; BAKER, J. F.; BYERS, F. M.; RECIO, H. A. Evaluation of live and carcass techniques for predicting beef carcass composition. Meat Science, Champaign, v. 23, n. 2, p. 111-129, 1988.

NATIONAL RESEARCH COUNCIL - NRC. Nutrient requirements of beef cattle. $7^{\text {th }}$ ed. National Academy Press: Washington, DC, 2000. 242 p.

. Nutrient requirements of small ruminants: sheep, goats, cervids, and new world camelids. $6^{\text {th }}$ ed. National Academy Press: Washington, DC, 2007. 384 p.

NOUR, A. Y. M.; THONNEY, M. L. Chemical composition of Angus and Holstein carcasses predicted from rib section composition. Journal of Animal Science, Champaign, v. 72, n. 5, p. 1239-1241, 1994.

PAULINO, P. V. R.; COSTA, M. A. L.; VALADARES FILHO, S. C.; PAULINO, M. F.; VALADARES, R. F. D.; MAGAlHÃES, K. A.; DETMAN, E.; PORTO, M. O.; MORAES, K. A. K. Validação das equações desenvolvidas por Hankins e Howe para predição da composição da carcaça de zebuínos e desenvolvimento 
de equações para estimativa da composição corporal. Revista Brasileira de Zootecnia, Viçosa, v. 34, n. 1, p. 327-339, 2005.

PERON, A. J.; FONTES, C. A. A.; LANA, R. P.; QUEIROZ, A. C.; SILVA, D. J.; FREITAS, J. A. Predição da composição corporal e da carcaça de bovinos através de métodos indiretos. Revista Brasileira de Zootecnia, Viçosa, v. 22, n. 2, p. 227-237, 1993.

POWEL, W. E.; HUFFMAN, D. L. An evaluation of quantitative estimates of beef carcass composition. Journal of Animal Science, Champaign, v. 27, n. 6, p. 1554-1558, 1968.

SILVA, F. F.; VALADARES FILHO, S. C.; ÍTAVO, L. C. V.; VElOSO, C. M.; PAUlino, M. F.; CECON, P. R.; PAULINO, P. V. R.; MORAES, E. H. B. K. Composição corporal e requisitos líquidos e dietéticos de macroelementos minerais de bovinos nelore nãocastrados. Revista Brasileira de Zootecnia, Viçosa, v. 31, n. 2, p. 757-764, 2002.

SNIFFEN, C. J.; O'CONNOR, D. J.; VAN SOEST, P. J.; FOX, D. G.; RUSSEL, J. B. A net carbohydrate and protein system for evaluating cattle diets: carbohydrate and protein availability. Journal of Animal Science, Champaign, v. 70, n. 11, p. 3562-3577, 1992.

STANFORD, K.; JONES, S. D. M.; PRICE, M. A. Methods of predicting lamb carcass composition: a review. Small Ruminant Research, Newton, v. 29, n. 3, p. 241-254, 1998.

STANFORD, K.; McALLISTER, T.; McDOUGALL, M.; BAILEY, D. R. C. Use of ultrasound for the prediction of carcass characteristics in Alpine goats. Small Ruminant Research, Newton, v. 15, n. 2, p. 195-201, 1985.
STATÍSTICAL ANALYSIS SYSTEM - SAS. System for windows. Release 9.1. Cary: SAS Institute, 2003.

TEIXEIRA, I. A. M. A. Methods to estimate body composition and nutritional requirements of F1 Boer $\times$ Saanen kids. 2004. PhD Thesis (Doctor in Animal Science) - State University of São Paulo, São Paulo.

TRENKLE, A. Use of urea and deuterium oxide to measure body composition. Journal of Animal Science, Champaign, v. 63, n., p. 96-101, 1986. Supplement 2.

VALADARES FILHO, S. C.; PAULINO, P. V. R.; MAGALHÃES, K. A. Exigências nutricionais de zebuínos e tabelas brasileiras de composição de alimentos para bovinos. Viçosa: Suprema Gráfica Ltda, 2006. $142 \mathrm{p}$.

VAN SOEST, P. J.; ROBERTSON, J. B.; LEWIS, B. A. Methods for dietary fiber, neutral detergent fiber, and nostarch polyssacharides in relation to animal nutrition. Journal of Dairy Science, Champaign, v. 74, n. 10, p. 3583-3597, 1991.

WEISS, W. P. Energy prediction equations for ruminant feeds. In: CORNELL NUTRITION CONFERENCE FOR FEED MANUFACTURERS, 1999, Ithaca. Proceedings... Ithaca: Cornell University, 1999. p. 176185.

WELLS, R. S.; PRESTON, R. L. Effects of repeated urea dilution measurement on feedlot performance and consistency of estimated body composition in steers of different breed types. Journal of Animal Science, Champaign, v. 76, n. 11, p. 2799-2804, 1998. 
